\title{
Is a Degree in Journalism and Mass Communication Still Worth Pursuing?
}

\section{Mary M Lamonica*}

Department of Journalism and Mass Communications, New Mexico State University, USA

The changes and challenges facing the media industry in the past decade have been well publicized. Revenue streams have been declining; delivery platforms are changing with readers switching from traditional paper-bound and broadcast news sources to digitized platforms; news staffs have been cut. And, digitization has changed the news industry's traditional notion of gate keeping. Now, anyone with access to a computer, tablet, or smart phone can post news and information. Inexpensive digital cameras also can provide video. With the rise of citizen reporters who provide news and visuals to many forms of mass media, the posting of news on social media sites, and the rise of Twitter, it may be fair to ask whether or not journalism and mass communication studies should still exist as a major for college and university students.

I believe such programs are still relevant. And, students apparently believe so, too. Indeed, students are still flocking to journalism and mass media programs. According to the 2010 Annual Survey of Journalism and Mass Communication Enrollments sponsored by the American Society of Newspaper Editors and a host of other news and educational organizations, student enrollments in mass communication programs are on the rise after a two-year period of malaise [1].

Such news is certainly heartening to professors such as me. More heartening, however, were the responses from my students on the value of a degree in mass media. When the spring 2012 semester began last month at my University, I asked students in my news writing class if they felt journalism was still a major worth pursuing given well-publicized stories about the downsizing of newsroom staffs, decreases in industry revenues, and the rise of non-traditional news and information sources via digital platforms. Surprisingly, and gratifyingly, they said yes. More importantly, they grasped several important points without my raising them:

1. The speed with which media organizations now post stories online means both accuracy and ethics are more important than ever. A simple mistake, even if corrected quickly, can still be seen by large numbers of individuals throughout the world and that mistake may make readers/viewers think less of the news organization's credibility.

2. Opening the gates and allowing more individuals access to a once exclusive news industry can provide much needed competition for traditional media organizations, but writing, reporting, and editing skills, visual journalism skills, ethics training, and a solid understanding of media law issues are all still needed.

3. Tweets are not news stories, although stories can be developed from tweets, and bloggers are not providing a service that parallels daily news content. Furthermore, bloggers are not necessarily credible since there is no editing or checking of their facts by other professionals.

4. News and information postings to social media also are not necessarily vetted and thus can lack the credibility that more traditional news industry practices can bring.

5. While students can and often do learn new digital methods of delivery at a faster pace than do some of their professors, my students recognize that learning how to report, how to check facts, how to learn to find good stories, to recognize what is newsworthy, and to learn how to ask good questions-the bread and butter critical thinking tools and skills necessary for industry professionals_-still are obtained through training.

Students, in other words, recognize that journalism and mass communication degrees are still valid and desirable. They still see media careers as worthy ones to pursue, but, equally importantly, they feel that training is necessary for those careers. Without such training, my students realize that the news industry's already fragile credibility can dip further. In other words, they want careers of which they can be proud. They want to consider their chosen area of work a profession. And, they recognize that the public, despite its many criticisms of the press, still turns to news and information on a daily basis.

Students also recognize that getting jobs upon graduation requires a combination of enterprise, internships, student media experience, networking, solid training, and a knowledge of digital platforms. With downsized newsrooms, they may get less guidance as interns than individuals received in previous decades. Yet, some good news is awaiting those students. The Pew Research Center's annual report entitled "The State of the News Media" for 2011 notes that revenues are starting to recover in most media industries and, subsequently, that hiring is increasing [2]. That hiring, however, may not be in traditional media industries. Online content providers such as Google and Yahoo provide news and thus need journalists to provide that information. Indeed, the Pew Research Center's Report finds that forty one percent of Americans said they get most of their news and information from the internet. Only local television news attracts a greater audience, according to the report. And, much of the audience is increasingly using their smart phones to obtain news. Our students, who have grown up in a digital environment, are often receptive to non-traditional media jobs.

The types of digital delivery platforms will undoubtedly continue

*Corresponding author: Mary M Lamonica, Department of Journalism and Mass Communications, New Mexico State University, USA, Tel: (575) 646-4638; E-mail: mlamonic@nmsu.edu

Received February 11, 2012; Accepted February 11, 2012; Published February 13,2012

Citation: Lamonica MM (2012) Is a Degree in Journalism and Mass Communication Still Worth Pursuing? J Mass Communicat Journalism 2:e116. doi:10.4172/21657912.1000 e116

Copyright: ( 2012 Lamonica MM. This is an open-access article distributed under the terms of the Creative Commons Attribution License, which permits unrestricted use, distribution, and reproduction in any medium, provided the original author and source are credited. 
Citation: Lamonica MM (2012) Is a Degree in Journalism and Mass Communication Still Worth Pursuing? J Mass Communicat Journalism 2:e116. doi:10.4172/2165-7912.1000e116

Page 2 of 2

to change in our field, as will the economics of our industry. Change is inevitable. An industry that once relied on the telegraph, the typewriter, the linotype machine, and reel-to-reel tape decks survived the demise of those technologies. The public still needs and relies on news and information, regardless of the technologies used to create and deliver that information. Furthermore, the dismaying statistics about revenue fears and decreases in hiring are industry trends that worry mass communication educators greatly, but ones that we recognize are surmountable.
The rise of new platforms for information delivery may have forced changes in industry structure and revenue streams, but core training in the skills necessary for fair, balanced, and accurate news stories will always be needed.

\section{References}

1. http://www.grady.uga.edu/annualsurveys/Enrollment_Survey/ Enrollment_2010/Enrollment_Report_2010_color.pdf

2. http://stateofthemedia.org/2011/ 